\title{
Anti-Cancer Acitivity of Etodolac and Its Derivatives on Prostate and Colorectal Cancer Cell Lines ${ }^{\dagger}$
}

\author{
Sevgi Koçyiğit Sevinç 1,*, Oya Orun ${ }^{1}$, Pınar Mega Tiber ${ }^{1}$, Pelin Çıkla-Süzgün ${ }^{2}$ and \\ Ş. Güniz Küçükgüzel ${ }^{2}$ \\ 1 School of Medicine, Department of Biophysics, Maltepe, Marmara University, 34854 Istanbul, Turkey; \\ oyaorun@yahoo.com (O.O.); pinarmet@yahoo.com (P.M.T.) \\ 2 School of Pharmacy, Department of Pharmaceutical Chemistry, Marmara University, Haydarpasa, \\ 34668 Istanbul, Turkey; pelin.cikla@marmara.edu.tr (P.C.-S.); gkucukguzel@marmara.edu.tr (S.G.K.) \\ * Correspondence: sevgikocyigit07@gmail.com \\ + Presented at the 2nd International Cell Death Research Congress, Izmir, Turkey, 1-4 November 2018. \\ Published: 7 December 2018
}

\begin{abstract}
Nonsteroidal anti-inflammatory drugs (NSAIDs) are commonly used as anti-inflammatory and analgesic agents. This family of drugs suppresses prostaglandin synthesis through inhibition of cyclooxygenase (COX) enzymes. Recent studies showed that anti-carcinogenic effects of these drugs are especially mediated by COX-2 enzyme. Etodolac is a COX-2 inhibitor and though not perfectly selective, it exhibits "preferential selectivity" for COX-2. In this study, the anti-proliferative and apoptotic effects of etodolac and its hydrazone or triazole derivatives (SGK 206 and SGK 242, respectively), were investigated on prostate cancer cell line PC-3 and human colorectal carcinoma cell line HT-29. Our data showed that SGK 206 and SGK 242 were more effective in the inhibition of proliferation and induction of apoptosis compared to etodolac in both cell lines.
\end{abstract}

Keywords: PC-3; HT-29; etodolac; cancer; apoptosis

\section{Introduction}

Nonsteroidal anti-inflammatory drugs (NSAIDs), regularly used for their anti-inflammatory and analgesic effects, were shown to have potency for cancer prevention as well [1]. This family of drugs suppresses prostaglandin synthesis through inhibition of cyclooxygenase (COX) enzymes. COX enzymes have two functional isoforms in human, COX-1 and COX-2. COX-1 is commonly expressed in body, showing constitutive activation. COX-2, on the other hand, is hardly detectable in normal conditions, but is induced upon stimulation by mitogenic agents, cytokines, growth factors etc.

Early reports about the role of NSAIDs in cancer were from the studies on colorectal cancer (CRC). Inducible form of COX enzymes, namely COX-2, was found to be elevated in CRC patients and early polyp formations were preceded by COX-2 induction [2]. Regular use of NSAIDs reportedly reduced CRC occurence $30-50 \%$, mostly by COX inhibition, though later studies revealed that COX-2 inhibitors could also act on COX-independent pathways [3]. These studies were further confirmed by many others and in different types of cancers like prostate, breast or lung cancers.

Etodolac ((R,S) 2-[1,8-diethyl-1,3,4-tetrahydrapyrano(3,4-b)indole-1-yl] acetic acid), is an FDAapproved NSAID partially selective for COX-2. Etodolac has different structural characteristics than other coxibs in that it has no sulfonyl, sulfonamide or sulfone groups to facilitate COX-2 binding. Its toxicity and relative selectivity for COX-2 is low, and although there are numerous studies about its anti-carcinogenic activity, dose-response relationship on various cancer cell lines are not well established. 
In this study, we focused on the anti-carcinogenic effects of etodolac and its hydrazone and triazole derivatives (SGK 206 and SGK 242, respectively) in two cancer cell lines. Both derivatives used in this study were synthesized and characterized by our collaborator .Dr.Küçükgüzel [4].

\section{Materials and Methods}

Both cell lines were maintained in DMEM medium, supplemented with 10\% FBS, $1 \%$ glutamine and penicillin/streptomycin at $37{ }^{\circ} \mathrm{C}$ with $5 \% \mathrm{CO}_{2}$ in atmosphere. Cell viability and growth inhibition were determined using MTT colorimetric assay, according to the instructions of manufacturer (Cell Proliferation Kit I (MTT), 11465007001, Roche, Indianapolis, USA). Briefly, cells were seeded into 96well plates and left to grow in the presence and absence of agents for indicated time points $(24,48$ and/or $72 \mathrm{~h}$ ). At the end of incubation period, $10 \mu \mathrm{L}$ of MTT was added to each well and incubated for $4 \mathrm{~h}$, at $37^{\circ} \mathrm{C}$ in $5 \% \mathrm{CO}_{2}$ humidified incubator. The precipitated formazan, then, dissolved in 100 $\mu \mathrm{L}$ SDS and the absorbance was read at $570 \mathrm{~nm}$ using a multi-mode plate reader (Synergy H1, BioTek Instruments Inc., Winooski, VT, USA).

Apoptosis was evaluated by measuring mitochondrial membrane potential changes (MMP assay). Cells were maintained in similar conditions described above, except black opaque 96-well plates were used for culturing. After exposure to appropriate drug for indicated time points, cells were stained with $1 \mu \mathrm{L}$ of JC-1 staining solution according to the protocol of kit, where JC-1, a lipophilic cationic dye with different absorbance wavelengths in healthy and apoptotic cells, was used to detect mitochondrial membrane depolarization (JC-1 Mitochondrial Membrane Potential Assay Kit, KA1324, Abnova, Taipei City, Taiwan). All tests were repeated at least three times (triplicate each) and statistical evaluation was performed using GraphPad Prism v5.0.

\section{Results and Discussion}

In our study, we investigated the effect of hydrazone and triazole derivatives of etodolac (SGK 206 and SGK 242) on prostate and colorectal cancer cell lines, PC-3 and HT-29. Novel hydrazone derivatives were found to be effective in the treatment of colon, ovarian, renal cancers $[5,6]$. One of the most benefical aspects of hydrazone groups is their preferential activity on malignant cells with respect to control cells. Triazoles are another candidate group with high biological activity. Antitumor activities for triazole derivatives were reported in colon adenocarcinoma, uterus carcinoma, cervical carcinoma, T cell leukemia and so on $[7,8]$. Based on these current evidences, hydrazone and triazole derivatives of etodolac were synthesized and tested for their anti-tumorigenic activities. All structures of the newly synthesized compounds were confirmed by spectral (FT-IR, 1H-NMR) methods.

Firstly, we studied low concentrations ( 0 to $100 \mu \mathrm{M})$ of etodolac on PC-3 cell line following 24 and $48 \mathrm{~h}$ incubation. No toxicity was observed in these low concentrations (data not shown). Therefore, PC-3 cells were treated with higher concentrations of etodolac $(100 \mu \mathrm{M}$ to $1000 \mu \mathrm{M})$ for 24 , 48 and $72 \mathrm{~h}$. Here, we observed that anti-proliferative and apoptotic effects of etodolac were only prominent after $500 \mu \mathrm{M}$ (Figure 1).

On the other hand, derivatives of etodolac had cytotoxic effects in much lower doses at the end of $24 \mathrm{~h}$ incubation on PC-3 cells. Both drugs showed cytotoxic effects when concentrations were increased from $25 \mu \mathrm{M}$ up to $100 \mu \mathrm{M}$. IC50 values for SGK 206 and SGK-242 were $40 \mu \mathrm{M}$ and $25 \mu \mathrm{M}$, respectively. Similar to proliferation, SGK 206 and SGK 242 showed apoptotic effects in much lower doses $(\geq 25 \mu \mathrm{M})$ (Figure 2). Apoptosis was $30 \%$ and $54 \%$ at $75 \mu \mathrm{M}$ and $100 \mu \mathrm{M}$ concentrations for SGK 206 and $28 \%$ and $89 \%$ at $25 \mu \mathrm{M}$ and $50 \mu \mathrm{M}$ concentrations for SGK 242 .

Derivatives of etodolac had cytotoxic effect on HT-29 cells as well (Figure 3). IC50 values for SGK 206 and SGK-242 were $70 \mu \mathrm{M}$ and $26 \mu \mathrm{M}$, respectively. 

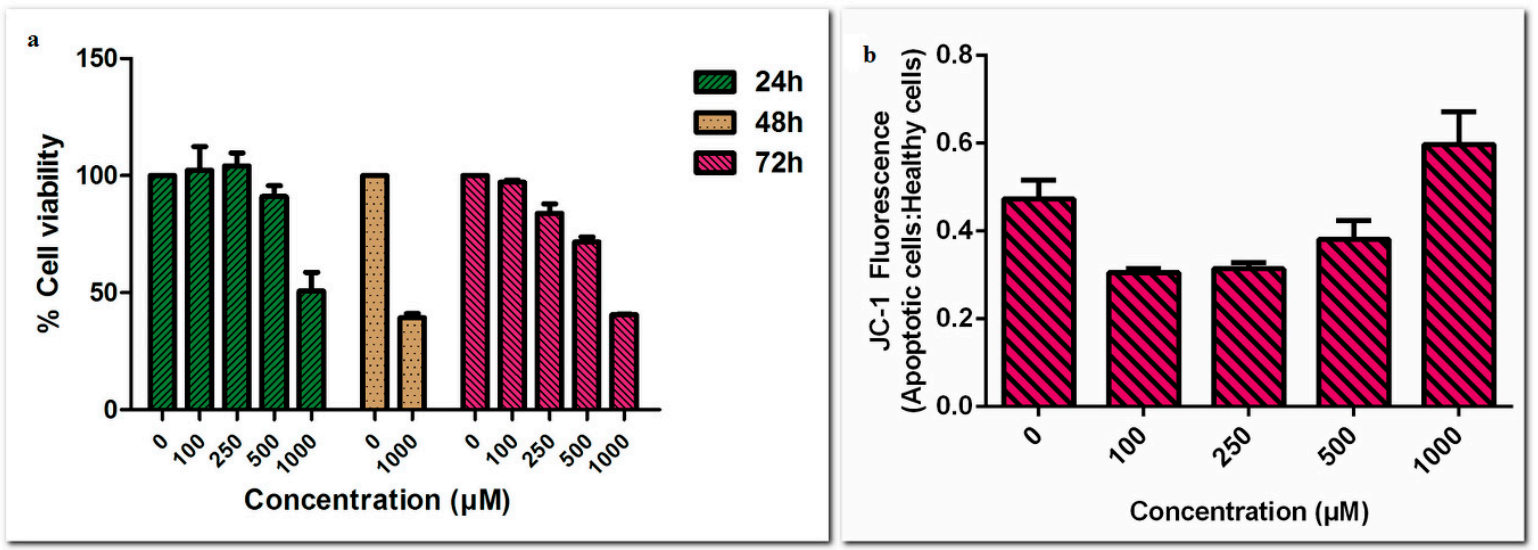

Figure 1. (a) Cell viability assay results following 24, 48 and $72 \mathrm{~h}$ incubations and (b) MMP assay results following $24 \mathrm{~h}$ incubation at high concentrations of etodolac $(0-1000 \mu \mathrm{M})$ in PC-3 cell line.
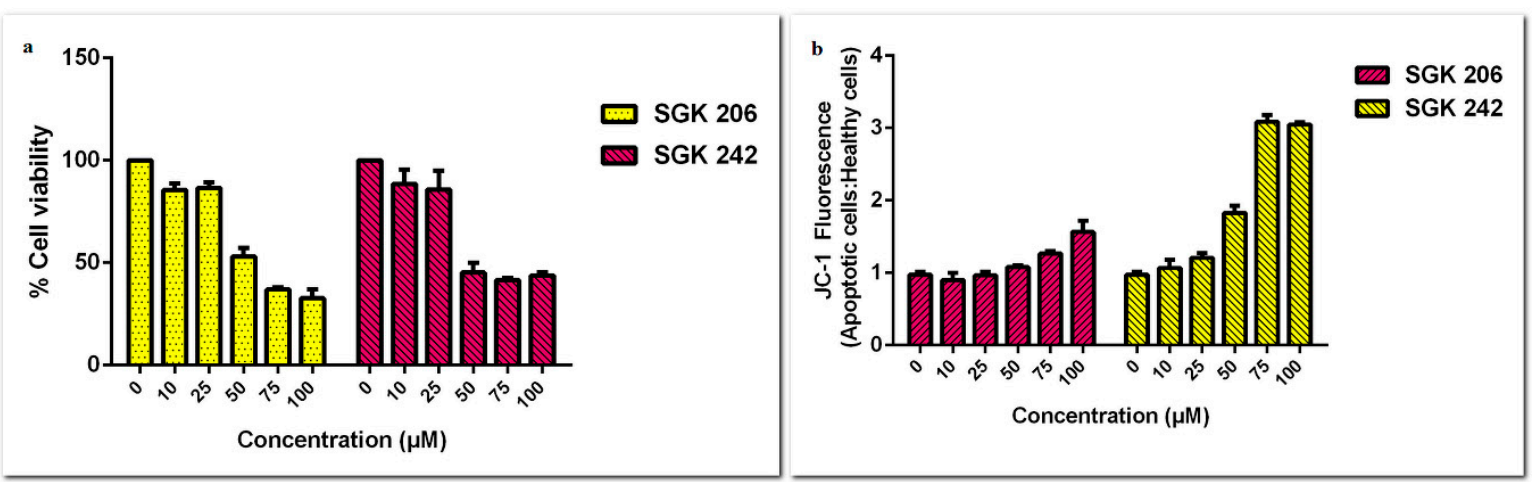

Figure 2. (a) Cell viability assay and (b) MMP assay results for different concentrations of SGK 206 and SGK $242(0-100 \mu \mathrm{M})$ following $24 \mathrm{~h}$ incubation in PC-3 cell line.

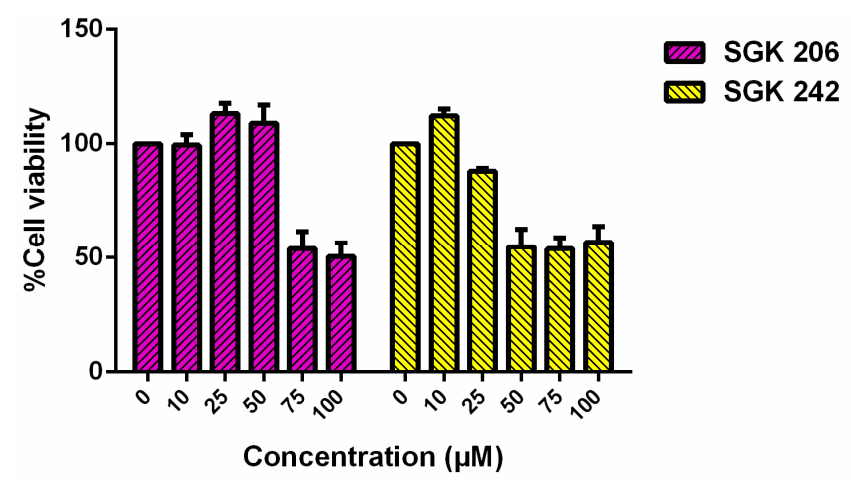

Figure 3. Cell viability assay results of HT-29 cell line for different concentrations of SGK 206 and SGK $242(0-100 \mu \mathrm{M})$ following $24 \mathrm{~h}$ incubation.

Our preliminary tests also showed that effects of both agents on control primary dermal fibroblasts are lower, especially in the case of SGK-242 (data not shown). Concentration dependent increase in apoptosis was in agreement with MTT viability tests as verified by higher apoptotic levels induced by SGK-242 and SGK-206 after $50 \mu \mathrm{M}$ concentrations. Detailed molecular mechanisms underlying these apoptotic responses are yet to be defined.

Findings of our study indicate that SGK 242 had substantial effects in inhibition of proliferation on PC-3 cells and HT-29 cells with respect to SGK-206 and had lower effect in control cells. While SGK-242 had same level of inhibition in both cell lines, SGK-206 was more efficient in PC-3 cells. Therefore both agents could be promising therapeutic targets in cancer treatments. 
Acknowledgments: This study was supported by Marmara University Research Fund SAG-C-DRP-1009140321.

\section{References}

1. Thun, M.J.; Henley, S.J.; Patrono, C. Nonsteroidal anti-inflammatory drugs as anticancer agents: Mechanistic, pharmacologic, and clinical issues. J. Natl. Cancer Inst. 2002, 94, 252-266.

2. Hsi, L.C.; Joon Baek, S.; Eling, T.E. Lack of Cyclooxygenase-2 Activity in HT-29 Human Colorectal Carcinoma Cells. Exp. Cell Res. 2000, 256, 563-570.

3. Kobayashi, M.; Nakamura, S.; Shibata, K.; Sahara, N.; Shigeno, K.; Shinjo, K.; Naito, K.; Ohnishi, K. Etodolac inhibits EBER expression and induces Bcl-2-regulated apoptosis in Burkitt's lymphoma cells. Eur. J. Haematol. 2005, 75, 212-220.

4. Çıkla-Süzgün, P.; Özsavcı, D.; Bingöl-Özakpınar, Ö.; Şener, A.; Çevik, Ö.; Özbaş-Turan, S.; Akbuğa, J.; Şahin, F.; Küçükgüzel, Ş.G. Synthesis, cytotoxicity, and pro-apoptosis activity of etodolac hydrazide derivatives as anticancer agents. Arch. Pharm. Chem. Life Sci. 2013, 346, 367-379.

5. Easmon, J.; Pürstinger, G.; Thies, K.S.; Heinisch, G.; Hofmann, J. Synthesis, structure-activity relationships, and antitumor studies of 2-benzoxazolyl hydrazones derived from alpha-( $N)$-acyl heteroaromatics. J. Med. Chem. 2006, 49, 6343-6350.

6. Küçükgüzel, Ş.G.; Koç, D.; Çıkla-Süzgün, P.; Özsavcı, D.; Bingöl-Özakpınar, Ö.; Mega-Tiber, P.; Orun, O.; Erzincan, P.; Sağ-Erdem, S.; Şahin, F. Synthesis of Tolmetin Hydrazide-Hydrazones and Discovery of a Potent Apoptosis Inducer in Colon Cancer Cells. Arch. Pharm. 2015, 348, 730-742.

7. Romagnoli, R.; Baraldi, P.G.; Cruz-Lopez, O.; Lopez Cara, C.; Carrion, M.D.; Brancale, A.; Hamel, E.; Chen, L.; Bortolozzi, R.; Basso, G.; et al. Synthesis and antitumor activity of 1,5-disubstituted 1,2,4-triazoles as cisrestricted combretastatin analogues. J. Med. Chem. 2010, 53, 4248-4258.

8. Kim, D.K.; Kim, J.; Park, H.J. Design, synthesis, and biological evaluation of novel 2-pyridinyl$[1,2,4]$ triazoles as inhibitors of transforming growth factor beta1 type 1 receptor. Bioorg. Med. Chem. 2004, $12,2013-2020$.

(C) 2018 by the authors. Licensee MDPI, Basel, Switzerland. This article is an open access article distributed under the terms and conditions of the Creative Commons Attribution (CC BY) license (http://creativecommons.org/licenses/by/4.0/). 